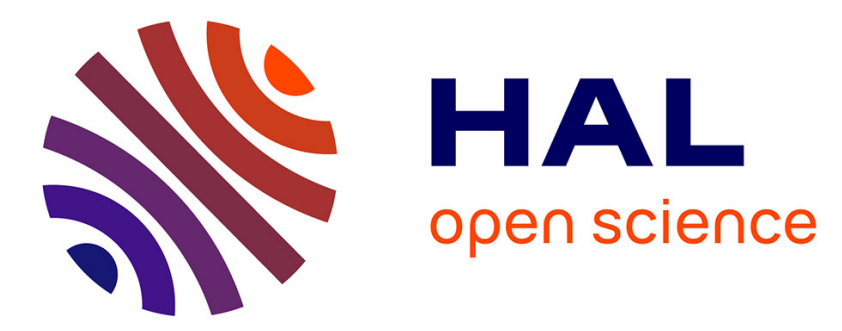

\title{
Monitoring of pathogenic microorganisms contamination during heat drying process of sewage sludge
}

\author{
Mohamed Hédi Romdhana, Didier Lecomte, Bruno Ladevie, Caroline
}

Sablayrolles

\section{- To cite this version:}

Mohamed Hédi Romdhana, Didier Lecomte, Bruno Ladevie, Caroline Sablayrolles. Monitoring of pathogenic microorganisms contamination during heat drying process of sewage sludge. Process Safety and Environmental Protection, 2009, 87 (6), pp.377 - 386. 10.1016/j.psep.2009.08.003 • hal-01651373

\section{HAL Id: hal-01651373 \\ https://imt-mines-albi.hal.science/hal-01651373}

Submitted on 7 Nov 2019

HAL is a multi-disciplinary open access archive for the deposit and dissemination of scientific research documents, whether they are published or not. The documents may come from teaching and research institutions in France or abroad, or from public or private research centers.
L'archive ouverte pluridisciplinaire HAL, est destinée au dépôt et à la diffusion de documents scientifiques de niveau recherche, publiés ou non, émanant des établissements d'enseignement et de recherche français ou étrangers, des laboratoires publics ou privés. 


\title{
Monitoring of pathogenic microorganisms contamination during heat drying process of sewage sludge
}

\author{
Mohamed Hédi Romdhana ${ }^{a, *}$, Didier Lecomte ${ }^{a}$, Bruno Ladevie $^{a}$, Caroline Sablayrolles $^{b, c}$ \\ a Université de Toulouse, MINES ALBI, RAPSODEE UMR CNRS 2392, Albi F 81013, France \\ $\mathrm{b}$ Université de Toulouse, INP, LCA (Laboratoire de Chimie Agro-Industrielle), ENSIACET, 4 Allées Emile Monso, F-31029 Toulouse, France \\ c INRA, LCA (Laboratoire de Chimie Agro-Industrielle), F-31029 Toulouse, France
}

\begin{abstract}
A B S T R A C T
The sewage sludge from wastewater treatment plant is a potential source of infectious organism. The number and type of pathogens in sludge depends on various factors namely, the wastewater source, the type of treatment plant, and other environmental factors such as the biological medium offered by the sewage sludge. The principal sludgeborne diseases are presented followed by discussion on biological aspect of growth and occurrence. The overall objective of this work is to estimate kinetic reduction of pathogen population in sludge during different thermaldrying process including: the agitated conductive drying, drum drying, solar drying, and fry-drying. The temperature curves were reported from literature except frying data which were determined in experiment. In order to apply the temperature influence on pathogens population, kinetic parameters for the thermal inactivation $(D, z$-values) were chosen from literature. Values of concentrations of each pathogen were also extracted from scientific review of pathogens in bio-solids. This study conducted to resolve the survival kinetic of Hepatitis A viruses. The result showed that a concentration of $7 \times 10^{4} \mathrm{cfu} / 100 \mathrm{ml}$ initially present in the sewage sludge is significantly reduced during the heat drying processes except the solar plant. The sewage sludge is completely disinfected when heated for $20 \mathrm{~min}$, $10 \mathrm{~min}$, and $10 \mathrm{~s}$, respectively, during the agitated conductive process, vacuum fry-drying, and drum drying process.
\end{abstract}

Keywords: Sewage sludge; Wastewater; Drying; Frying; Solar; Pathogens; Microbial disease; Microorganism; Thermal inactivation

\section{Introduction}

Sewage sludge is the residue formed through wastewater treatment plant. The most significant health hazard for sewage sludge relates to the wide range of pathogenic microorganisms. Pathogens are present in sludge as result of: human and animal wastes, food processing, biological laboratory and during some treatment of wastewater. These pathogens are divided into four categories (EPA, 1979): viruses, bacteria, parasites, and fungi. Within each one, there are various species with different occurrences. With lower levels of sanitation and less public awareness, many diseases and infections can occur (hepatitis, typhoid fever, etc.). The risk of contamination can arise by simple touch or consumption of products that have been contaminated from animals, insects, land or water (EPA, 1995). Therefore, hygienic principles must be followed in processing, storage or transport of sewage sludge. In order to defeat the biological risk related to sludge disposal, some processes are available with various degrees of pathogen reduction. For example: ionizing radiation, composting, storage and other chemical disinfection. The irradiation process involves exposing sludge to a source of radian energy (Ahlstrom, 1988). High energy electron and photon ( $\beta$ - and $\gamma$-rays) are usually used because of their penetration power (EPA, 1979). The easiest conditioner treatment of sewage sludge is composting. The organic matters are decomposed to stable humus under the aerobic thermophilic conditions (more than $55^{\circ} \mathrm{C}$ for 15 days or more) enough for heat inactivation (Nazih and Lawrence, 2007). Nevertheless, not all the material is heated and pathogens risk

\footnotetext{
* Corresponding author.

E-mail address: romdhana@enstimac.fr (M.H. Romdhana).
} 


$$
\begin{array}{ll}
\text { Nomenclature } \\
\mathrm{D} & \text { decimal reduction time }(\mathrm{s}) \\
\mathrm{N} & \text { microorganisms population } \\
\mathrm{T} & \text { temperature }\left({ }^{\circ} \mathrm{C}\right) \\
\mathrm{t} & \text { time }(\mathrm{s}) \\
\mathrm{Z} & \text { temperature sensitive parameter }\left({ }^{\circ} \mathrm{C}\right)
\end{array}
$$

re-growth (Björn, 2007). The destruction of pathogens can also be achieved by chemicals stabilization, including lime, chlorine and its compound, quaternary ammonium, ozone, etc. The most common disinfectants are the oxidizing chemicals among them chlorine is the most used (Tchobanoglous et al., 2003); it is effective for bacteria and viruses inactivation but not for parasite (Lawrence et al., 2007a). Highly acid or alkaline water can also be used to destroy pathogenic organism, because water with $\mathrm{pH}$ greater than 11 or less than 3 is relatively toxic to most microorganisms (Clint et al., 2007). High pH treatment is typically obtained with lime at $\mathrm{pH}$ higher than 12 for $3 \mathrm{~h}$ (Rolf et al., 1991). Long term storage is another way to destroy pathogen. Hence, sludge is stored in earthen lagoon. Typical detention times for disinfection are 60 days at $20^{\circ} \mathrm{C}$ and 120 days at $4{ }^{\circ} \mathrm{C}$ (Rolf et al., 1991). Another means of inactivating pathogens is heat application to sludge. Heat may be used at low temperature as in pasteurization using a direct steam injection or a heat exchanger. A pasteurization system should be designed to provide a uniform minimum temperature of $63^{\circ} \mathrm{C}$ for at least 30 min (James, 2006; Nissen et al., 1996). All pathogens can be also destroyed for a shorter time period of $10 \mathrm{~min}$ at $91^{\circ} \mathrm{C}$ (EPA, 1979). Tyndallization is equivalent to repeated pasteurization and separated by period of $12-24 \mathrm{~h}$ at $30-40^{\circ} \mathrm{C}$ (Joseph, 2003). Heat conditioning-dewatering processes use a higher temperature than pasteurization $\left(140-240^{\circ} \mathrm{C}\right)$ for a period of 15-60 min under a pressure of 17-27 bars (Lawrence et al., 2007b). Ultrasound can be combined with conventional thermal treatment based on the possible synergy between low frequency ultrasound and heat for pathogen inactivation (Zenker et al., 2003), however its use in food industry is unfeasible and requires the addition of antimicrobial compounds (Aurelio et al., 2004). Other heating processes including incineration, vapor-gasification and pyrolysis, raise the sludge temperature by more than $500^{\circ} \mathrm{C}$ destroying the physical structure of all sludge pathogens and effectively sterilizing the sludge (Werther and Ogada, 1999). In this study the drying treatment was adopted in order to produce a solid biofuel from wet wastewater sludge. Therefore sludge disinfection as an add-on drying process becomes necessary for storage or handling before combustion. Drying energy is subdivided into heat conditioning and heat drying. Heat conditioning includes thermal energy required to increase sludge temperature and to inactivate pathogenic microorganisms. Heat acts on the level of molecular agitation. It causes an increase on the growth speed and mutation of microbial compound. When the level of modification becomes important and irreversible the growth decreases and stops and microorganisms die (Joseph, 2003). The destruction reactions rates of microorganisms are not depend on the temperature (Paul and Dennis, 2001).

The overall objective of this work is to estimate kinetic reduction of pathogen population in sludge during different thermal-drying process including: agitated conductive drying, drum drying, solar drying, and fry-drying. The best conditions (temperature, time) of drying which insure a good microbial destruction were chosen.

\section{Pathogenic organisms}

\subsection{Sludge-borne disease}

The pathogenic organisms found in sewage sludge can be classified into four broad categories: viruses, bacteria, parasites and fungi (EPA, 1979). Viruses are classified as most pathogenic microorganism; the most important human enteric viruses are the enteroviruses (polio, echo, coxsackie), Norwalk, rotaviruses, reoviruses, adenoviruses and hepatitis A and E (Tchobanoglous et al., 2003; Vantarakis and Papapetropoulou, 1998). Diseases caused by enteric viruses range from trivial to severe or even fatal, and the most common form of transmission include the fecal-oral and respiratory routes of infection (Ian et al., 2006). Norwalk and rotaviruses are causative agent of diarrhea diseases and shown to be major waterborne pathogens (Bosch et al., 2006). The reoviruses and adenoviruses may cause respiratory illness, gastroenteritis and eye infection (Tchobanoglous et al., 2003). Enteroviruses are the most responsible for a wide variety of illnesses in humans, including meningitis, myocarditis, febrile illness, paralysis, respiratory infections, certain type of diabetes, and eye and skin infections (Ian et al., 2006). Hepatitis $A$ and $E$ have almost the similar syndrome (anorexia, faint, etc.), but the hazard fatality is higher with hepatitis $E$ than A and rises to $15-25 \%$ in pregnant women (Anna and Richard, 2006).

The second group of pathogenic contains the family of the harmful bacteria. A wide variety and concentration range of bacteria are found in domestic wastewater. One of the most common bacterial pathogens is the genus salmonella. Among this specie, salmonella typhi is the most severe and serious (Tchobanoglous et al., 2003). The pathogen produce a toxin that cause fever (such us typhoid fever), nausea, and diarrhea, and may be fatal if not properly treated (Ian et al., 2006). Shigella, a less common genus of bacteria, is often found in wastewater polluted with human sewage, raw vegetable, milk and dairy products and poultry (Tchobanoglous et al., 2003; Ian et al., 2006). Only four species are recognized (dysenteriae, flexneri, boydii, and sonnei) and responsible to various intestinal diseases known as shigellosis (James et al., 2008a). Other bacteria found in sewage sludge include: vibrio, Mycobacterium, clostridium, leptospira, yersinia, Escherichia coli species and campylobacter (Tchobanoglous et al., 2003). Vibrio consists of at least 28 species, in which vibrio cholera known as the cause of human cholera (James et al., 2008b). The more interest species in the genus yersinia is yersinia enterocolitica, its symptoms are fever, diarrhea, severe abdominal pain, vomiting and headache, and its incidence is highest in the very young and the old (James et al., 2008b). Campylobacter jejuni is one of primary important species in genus campylobacter and is identified as the cause of diarrhea in human (Tchobanoglous et al., 2003).

The third group of pathogenic contains the family of parasites, including: protozoa, nematodes, and helminthes (EPA, 1979). The most concerned protozoan species are cryptosporidium parvum, cyclospora and giardia lamblia because of their significant impact on individuals with compromised immune system (Tchobanoglous et al., 2003; Ian et al., 2006). The more common nematodes are Trichinella and Anisakis 
(Ynes, 2006), they may invade tissues (eye, encysts) other than the intestine causing inflammation and fibrosis (EPA, 1979; Bosch et al., 1986). Helminthic parasites include flatworms such as tapeworms (EPA, 1979). They are detectable as eggs in bio-solids, and they are capable to produce larvae that infect people (Ian et al., 2006). In the less serious form, the tapeworm develops in the intestine, maturing and releasing eggs. In the more serious form, it localizes in the ear, eye, heart, or central nervous system (EPA, 1979).

The last groups of pathogenic are fungal species. They are secondary pathogens in wastewater sludge particularly in compost. The most prevalent fungi are Actinomyces, Aspergillus, and Candia albicans (EPA, 1979). Several species are also animal and human mycotoxigenic agents (AliShtayeh et al., 1998). They may be a potential hazard for the people handling the sludge and possibly also during food and feed production from soil amended with residue or organic fertilizers (Anna and Johan, 2006).

\subsection{Growth and biological property}

Viruses, bacteria, parasites and fungi show varying resistances to environmental factors such as heat, moisture, chemical and physical agents. The parameter of $\mathrm{pH}$ influences the chemical and biochemical reaction and therefore the microorganisms. Most bacteria are stable at $\mathrm{pH} \leq 8.5$ and $\geq 1.5$ (Bourgeois et al., 1996), but some are more sensitive such as Salmonella which is destroyed if the pH is below 4.0 (James et al., 2008a). Several viruses are acid-resistant such as Hepatitis A which is stable at $\mathrm{pH} \geq 1.0$ and $\leq 3.75$ (Sagar, 2007). Most fungi are acid-tolerant, but they are also able to growth under neutral or even alkaline $\mathrm{pH}$ such as Aspergillus (Bourgeois et al., 1996; Sabine and Eleanora, 2000). Heat resistant of microorganism changes also according to the water activity in the sludge. The presence of a solute substance decreases water activity and thus increases heat resistance of microorganism (Bourgeois et al., 1996). The upper growths of pathogens require high water activity, more than 0.91 and 0.87 for bacteria and fungi, respectively (Bourgeois et al., 1996). In addition, the pathogens are resistant to various chemical agents including acid and alkaline solvents. Indeed, Hepatitis A is very stable, showing resistant to several preservatives and solvents including chloroform, Freon, Arklone, perchloroacetic acid or chloramines (Sagar, 2007). Rotaviruses are also resistant to ether, chloroform, and to non-ionic detergents such as deoxycholate (Sagar, 2007). Generally, bacteria are enable to tolerate high salt concentration such as Salmonella and Shigella which shown to be inhibited by nitrite (James et al., 2008a). Parasites (Ascaris, Giardia) are typically very resistant to the level of chlorine (EPA, 1979; Irshad and Vitaliano, 2006). On the other hand, the temperature of the medium influences the growth and the thermal resistance of pathogens. Different species and their subspecies show different sensitivities to elevated temperatures and duration of exposure. Hepatitis A retains integrity and infectivity after $60 \mathrm{~min}$ incubation at $60^{\circ} \mathrm{C}$, and Nerovirus retains infectivity when heated to $60^{\circ} \mathrm{C}$ for $30 \mathrm{~min}$ (Sagar, 2007). Therefore, Hepatitis A and Nerovirus are not inactivated by pasteurization treatment. However, Adenovirus is more sensible and is inactivated after heating at $56^{\circ} \mathrm{C}$ for more than $10 \mathrm{~min}$ (Sagar, 2007). For bacteria, temperature around $44-48^{\circ} \mathrm{C}$ is reported to be the upper limit for growth (James et al., 2008a,b). $50^{\circ} \mathrm{C}$ is an effective temperature for reducing the population of Salmonella over a $30 \mathrm{~min}$ time scale (Ward and Brandon, 1977). Campylobacter heating to $70^{\circ} \mathrm{C}$ could not be detected after about $10 \mathrm{~min}$ (James et al., 2008b). Yersiniae represent a less resistant group which destroyed in 1-3 $\mathrm{min}$ at $60^{\circ} \mathrm{C}$ (James et al., 2008b). Potential disadvantage with lower temperature, the presence of organics and the high concentration of bacteria may promote survival or even re-growth. For example, Vibrio can survive $80^{\circ} \mathrm{C}$ for $15 \mathrm{~min}$ (James et al., 2008b). Moderate temperatures around $55^{\circ} \mathrm{C}$ for less than $10 \mathrm{~min}$ are effective in eliminating viability of some parasites in water or liquid sludge (Ward and Brandon, 1977). Finally, the majority of fungi can be destroyed by heating at temperatures until $88^{\circ} \mathrm{C}$ during 30-60 min (Hersom and Hulland, 1980); for example, Aspergillus fungi are inactivated at $60^{\circ} \mathrm{C}$ for $60 \mathrm{~min}$ (EPA, 1979).

\section{Pathogenic occurrence in sewage sludge}

The examination of pathogens occurrence is reported for different type of sludge from various sources. Throughout the literature survey, the data presented are obtained from different wastewater plant and vary from raw wastewater to final effluent. In addition the review of scientific literature reveals different methods of analysis. Indeed, the enumeration is carried out by (Tchobanoglous et al., 2003; James et al., 2008a): (1) direct microscopic count, (2) colony forming units (cfu), with culture in solid medium, and (3) the most probable number (MPN) method as a statistical determination.

According to: (1) the relative difficulty of the process preparing, (2) the costly method, and (3) time consuming (Tchobanoglous et al., 2003; Joret et al., 1980), only a few data on Rotavirus (Bosch et al., 1986) and Adenovirus (Williams and Hurst, 1988) are available. A few data of presence/absence of Enterovirus, Adenovirus and Hepatitis A viruses (Vantarakis and Papapetropoulou, 1988) are also available. Most data are reported on Enteroviruses and the total concentration of enteric viruses in sludge. Typical total virus concentrations are given in Table 1 . The large difference between the high and low value for the number of virus results from several factors, including variation in virus occurrence in human population, differing treatment plant removal efficiency and identification techniques. Anaerobic digestion, dewatering and composting have been shown to reduce the concentration of detectable viruses.

Commonly found concentrations of bacteria are shown in Table 1. A significant reduction of average concentration of enteric bacteria is observed during wastewater treatment plant. In general, anaerobic digestion of sludge is the most effective for most bacteria. Nevertheless, Mycobacterium is shown very resistive during anaerobic digestion. Literature of this subject has been reviewed in reference Wéry et al. (2008) on the survival of different enteric bacteria during biological treatment. The study showed that Campylobacter jejuni survived better than other enteric bacteria. In this context also, an experimental identification (absence/presence) of bacterial pathogens during sewage treatment plant is reported in reference Leena et al. (2004). Salmonella is the most common in both raw and treated sludge, Campylobacter is found in $20 \%$ in raw sludge and $4 \%$ in treated sludge, and Listeria number found decreases from 12 to $2 \%$.

There is a wide variation in the apparent level of parasite infestation in different wastewater treatment stages. Limited data for Protozoa, Helminths, and Nematodes reported in Table 2, indicate that Nematodes eggs and Ascaris are detected in small numbers. Cryptosporidium and Giardia Lamblia are 
Table 1 - Virus and bacteria occurrence in raw sludge and various step of wastewater treatment plant.

\begin{tabular}{|c|c|c|c|c|}
\hline Pathogen & Name of species & Treatment stage & Concentration & References \\
\hline \multirow[t]{11}{*}{ Virus } & \multirow[t]{3}{*}{ Enteric viruses } & Raw sludge & $\begin{array}{l}2.5 \times 10^{3}-7 \times 10^{4} \mathrm{cfu} / 100 \mathrm{ml} \\
10^{3}-10^{4} \mathrm{MPN} / 100 \mathrm{ml}\end{array}$ & $\begin{array}{l}\text { EPA (1979) } \\
\text { Tchobanoglous et al. (2003) }\end{array}$ \\
\hline & & Digested sludge & $100-10^{3} \mathrm{cfu} / 100 \mathrm{ml}$ & EPA (1979) \\
\hline & & Secondary wastewater & $0.3-115 \mathrm{MPN} / 1$ & Joret et al. (1980) \\
\hline & \multirow[t]{6}{*}{ Enteroviruses } & \multirow[t]{3}{*}{ Raw sludge } & $4.8 \times 10^{2}-2.1 \times 10^{3} \mathrm{cfu} / 10 \mathrm{~g}$ dry matter & Guzmán et al. (2007) \\
\hline & & & $850-43 \times 10^{3} \mathrm{cfu} / 1$ & Bosch et al. (1986) \\
\hline & & & $1320 \mathrm{cfu} / \mathrm{l}$ & Williams and Hurst (1988) \\
\hline & & Digested sludge & $1.1 \times 10^{1}-1 \times 10^{2} \mathrm{cfu} / 10 \mathrm{~g}$ dry matter & \multirow[t]{3}{*}{ Guzmán et al. (2007) } \\
\hline & & Dewatered sludge & $1.8 \times 10^{1}-4.1 \times 10^{1} \mathrm{cfu} / 10 \mathrm{~g}$ dry matter & \\
\hline & & Composted sludge & $<8.3 \mathrm{cfu} / 10 \mathrm{~g}$ dry matter & \\
\hline & Rotavirus & Primary sludge & $30-26 \times 10^{4} \mathrm{cfu} / \mathrm{l}$ & Bosch et al. (1986) \\
\hline & Adenovirus & Primary sludge & $5,800-32,500 \mathrm{cfu} / \mathrm{l}$ & Williams and Hurst (1988) \\
\hline \multirow[t]{31}{*}{ Bacteria } & \multirow[t]{2}{*}{ Enteric bacteria } & Raw sewage & $5.6 \times 10^{6} \mathrm{ml}^{-1}$ & \multirow[t]{2}{*}{ Bridge (1970) } \\
\hline & & Final product & $0.5 \times 10^{6} \mathrm{ml}^{-1}$ & \\
\hline & \multirow[t]{6}{*}{ Salmonella } & \multirow[t]{3}{*}{ Raw sludge } & $8 \times 10^{3} \mathrm{cfu} / 100 \mathrm{ml}$ & EPA (1979) \\
\hline & & & $10^{2}-10^{4} \mathrm{MPN} / 100 \mathrm{ml}$ & Tchobanoglous et al. (2003) \\
\hline & & & $10^{3}$ gene $/ \mathrm{ml}$ & Wéry et al. (2008) \\
\hline & & Digested sludge & $<3-62 \mathrm{cfu} / 100 \mathrm{ml}$ & EPA (1979) \\
\hline & & Dewatered sludge & $5 \times 10^{4}$ gene $/ \mathrm{ml}$ & Wéry et al. (2008) \\
\hline & & Centrifugation & $<10$ gene $/ \mathrm{ml}$ & \\
\hline & \multirow[t]{8}{*}{ Escherichia coli } & \multirow[t]{2}{*}{ Raw sludge } & $357,275-1,032,625 \mathrm{cfu} / \mathrm{g}$ & Leena et al. (2004) \\
\hline & & & $10^{7}-10^{8}$ gene $/ \mathrm{ml}$ & Wéry et al. (2008) \\
\hline & & Digested sludge & $2-8435 \mathrm{cfu} / \mathrm{g}$ & Leena et al. (2004) \\
\hline & & \multirow{2}{*}{ Dewatered sludge } & 4-6 log MPN/g dry matter & Gantzer et al. (2001) \\
\hline & & & $10^{7}-5 \times 10^{8}$ gene $/ \mathrm{ml}$ & Wéry et al. (2008) \\
\hline & & \multirow[t]{2}{*}{ Centrifugation } & $6,233-403,571 \mathrm{cfu} / \mathrm{g}$ & Leena et al. (2004) \\
\hline & & & $10^{4}$ gene $/ \mathrm{ml}$ & Wéry et al. (2008) \\
\hline & & Limed sludge & $<1-2.9 \log$ MPN/g dry matter & Gantzer et al. (2001) \\
\hline & Shigella & Raw wastewater & $1-10^{3} \mathrm{MPN} / 100 \mathrm{ml}$ & Tchobanoglous et al. (2003) \\
\hline & \multirow{9}{*}{ Clostridium } & \multirow[t]{4}{*}{ Raw wastewater } & $6 \times 10^{6} \mathrm{cfu} / 100 \mathrm{ml}$ & EPA (1979) \\
\hline & & & $10^{3}-10^{5} \mathrm{MPN} / 100 \mathrm{ml}$ & Tchobanoglous et al. (2003) \\
\hline & & & $172,857-174,524 \mathrm{cfu} / \mathrm{g}$ & Leena et al. (2004) \\
\hline & & & $10^{2}-10^{4}$ gene $/ \mathrm{ml}$ & Wéry et al. (2008) \\
\hline & & \multirow[t]{2}{*}{ Digested sludge } & $2 \times 10^{7} \mathrm{cfu} / 100 \mathrm{ml}$ & EPA (1979) \\
\hline & & & $60,667-106,571 \mathrm{cfu} / \mathrm{g}$ & Leena et al. (2004) \\
\hline & & \multirow[t]{2}{*}{ Centrifugation } & $37,667-438,650 \mathrm{cfu} / \mathrm{g}$ & \multirow{3}{*}{ Wéry et al. (2008) } \\
\hline & & & 10 gene $/ \mathrm{ml}$ & \\
\hline & & Dewatered sludge & $10^{3}-10^{6}$ gene $/ \mathrm{ml}$ & \\
\hline & \multirow[t]{2}{*}{ Mycobacterium } & Raw sludge & $10^{7} \mathrm{cfu} / 100 \mathrm{ml}$ & \multirow[t]{2}{*}{ EPA (1979) } \\
\hline & & Digested sludge & $10^{6} \mathrm{cfu} / 100 \mathrm{ml}$ & \\
\hline & \multirow[t]{3}{*}{ Campylobacter jejuni } & Wastewater & $10-10^{3}$ gene $/ \mathrm{ml}$ & \multirow[t]{3}{*}{ Wéry et al. (2008) } \\
\hline & & Dewatered sludge & $10^{6}$ gene $/ \mathrm{ml}$ & \\
\hline & & Centrifugation & 5-10 gene/ml & \\
\hline
\end{tabular}

detected in high number in raw sludge; they are considerably greater on pig farms (Roberto and Eloy, 2008). Treatments by activation sludge process, composting or lime, reduced the number of parasites, but are reported to incompletely remove all pathogens. For example, the total concentration of Nematodes eggs in the sludge is not greatly after treatment, but it stills lower than sanitized concentration ( $<3$ eggs/10 g dry matter (Gantzer et al., 2001)). The reduction with the heat drying procedure (Roberto and Eloy, 2008) is greater than other technologies such as anaerobic/aerobic digestion, lime stabilization or composting. Heat drying greatly reduces the number of parasites by more than $4 \log$ (Roberto and Eloy, 2008) units for Cryptosporidium oocysts, confirming the effect of the temperature on the destruction of parasites.

Data for fungi are sparse; limited data for fungi occurrence in the sludge reported in Table 2 include Aspergillus fumigatus, Yeast-like, Filamentous and average number of total fungi. There is a wide frequency of the fungi in the sludge.
Fungi occurrence is considerably dependent to the habitat in which fungi cells are continually bathed in a nutrient medium offered by the sewage sludge. Levels vary at each wastewater treatment stage, temperature, moisture content, and also weather. It is noted (Bridge and Wesley, 1968) that certain subspecies or growth types of the fungi are more prominent in the winter, other in the warmer month.

\section{Kinetics of thermal disinfecting}

\subsection{Basic kinetic equations}

In order to determine the required time for a given drying process, it is necessary to have information on heat penetration and its effect on the inactivation of microorganisms. The heat penetration is measured by placing a thermocouple at the centre of sewage sludge to record the temperature during drying. In fact, all other points in dried product are assumed to 
Table 2 - Parasites and fungi occurrence in raw sludge and various step of wastewater treatment plant.

\begin{tabular}{|c|c|c|c|c|}
\hline Species & Subspecies & Treatment stage & Occurrence & References \\
\hline \multicolumn{5}{|l|}{ Parasites } \\
\hline \multirow[t]{11}{*}{ Protozoa } & Cryptosporidium & Raw wastewater & $10-10^{3} \mathrm{MPN} / 100 \mathrm{ml}$ & Tchobanoglous et al. (2003) \\
\hline & & & $1.1 \times 10^{3}$ oocysts $/ 10 \mathrm{~g}$ dry matter & Guzmán et al. (2007) \\
\hline & & Digested sludge & $3.6 \times 10^{2}$ oocysts $/ 10 \mathrm{~g}$ dry matter & \\
\hline & & Sewage sludge & $12-17$ oocysts/g & Thaddeus et al. (2008) \\
\hline & & Swine slurry & $1.67 \times 10^{4}-2.33 \times 10^{5}$ oocysts $/ 1$ & Roberto and Eloy (2008) \\
\hline & & Dried sludge & $3.5 \times 10^{3}-1.03 \times 10^{4}$ oocysts $/ \mathrm{kg}$ & \\
\hline & Giardia Lamblia & Raw wastewater & $10^{3}-10^{4} \mathrm{MPN} / 100 \mathrm{ml}$ & Tchobanoglous et al. (2003) \\
\hline & & Sewage sludge & $22-32$ cysts/g & Thaddeus et al. (2008) \\
\hline & & Swine slurry & $3.33 \times 10^{3} \mathrm{cysts} / \mathrm{l}$ & Roberto and Eloy (2008) \\
\hline & & Activated sludge & Not detected & \\
\hline & & Dried sludge & Not detected & \\
\hline \multirow[t]{6}{*}{ Helminth } & Eggs & Raw wastewater & $10-10^{3} \mathrm{MPN} / 100 \mathrm{ml}$ & Tchobanoglous et al. (2003) \\
\hline & & & 1.2 eggs/10 g dry matter & Guzmán et al. (2007) \\
\hline & & Digested sludge & 1.7 eggs/10 g dry matter & \\
\hline & & Swine slurry & $100-2600$ eggs/1 & Roberto and Eloy (2008) \\
\hline & & Dried sludge & Not detected & \\
\hline & Ascaris & Raw wastewater & $10^{-2}-1 \mathrm{MPN} / 100 \mathrm{ml}$ & Tchobanoglous et al. (2003) \\
\hline \multirow[t]{5}{*}{ Nematode } & Eggs & Raw sludge & $2-53$ eggs/10 g dry matter & Gantzer et al. (2001) \\
\hline & & Anaerobic digestion & $16.7 \pm 10.3$ eggs $/ 10 \mathrm{~g}$ dry matter & \\
\hline & & Aerobic digestion & $5 \pm 3.7$ eggs $/ 10 \mathrm{~g}$ dry matter & \\
\hline & & Compost & $6.2 \pm 6.7$ eggs $/ 10 \mathrm{~g}$ dry matter & \\
\hline & & Limed sludge & $2.7 \pm 1.5-28.7 \pm 16.6$ eggs $/ 10 \mathrm{~g}$ dry matter & \\
\hline \multicolumn{5}{|l|}{ Fungi } \\
\hline \multirow[t]{5}{*}{ Filamentous } & & Raw sludge & $1.2 \times 10^{3}-9 \times 10^{3}$ colonies $/ \mathrm{ml}$ & Bridge (1970) \\
\hline & & & $0.2 \times 10^{6}-10.3 \times 10^{6}$ colonies $/ \mathrm{ml}$ & Bridge and Wesley (1968) \\
\hline & & Settle sewage & $0.3 \times 10^{6}-3.2 \times 10^{6}$ colonies $/ \mathrm{ml}$ & \\
\hline & & Waste sludge & $0.23 \times 10^{3}-23 \times 10^{3}$ colonies $/ \mathrm{ml}$ & Bridge (1970) \\
\hline & & & $152.4 \times 10^{6}-750.4 \times 10^{6}$ colonies $/ \mathrm{ml}$ & Bridge and Wesley (1968) \\
\hline \multirow[t]{5}{*}{ Yeast-like } & & Raw sludge & $10^{4}-10^{6}$ colonies $/ \mathrm{ml}$ & Bridge (1970) \\
\hline & & & $0.07 \times 10^{5}-0.2 \times 10^{5}$ colonies $/ \mathrm{ml}$ & Bridge and Wesley (1968) \\
\hline & & Settle sewage & $0.03 \times 10^{5}-1.2 \times 10^{5}$ colonies $/ \mathrm{ml}$ & \\
\hline & & Waste sludge & $10^{2} \times 10^{5}-0.3 \times 10^{5}$ colonies $/ \mathrm{ml}$ & Bridge (1970) \\
\hline & & & $1.5 \times 10^{5}-100.9 \times 10^{5}$ colonies $/ \mathrm{ml}$ & Bridge and Wesley (1968) \\
\hline Aspergillus & & Raw sludge & $10^{2}-10^{3} \mathrm{cfu} / \mathrm{g}$ dry weight & Millner et al. (1977) \\
\hline \multirow[t]{7}{*}{ Total fungi } & & Raw sewage & $3.9 \times 10^{3} \mathrm{ml}^{-1}$ & Bridge (1970) \\
\hline & & & $2.3 \times 10^{4}-5.4 \times 10^{4} \mathrm{cfu} / \mathrm{g}$ dry weight & Millner et al. (1977) \\
\hline & & & $0.4 \times 10^{6}-10.4 \times 10^{6}$ colonies $/ \mathrm{ml}$ & Bridge and Wesley (1968) \\
\hline & & Settle sewage & $4.4 \times 10^{3} \mathrm{ml}^{-1}$ & Bridge (1970) \\
\hline & & & $1.4 \times 10^{6}-3.3 \times 10^{6}$ colonies $/ \mathrm{ml}$ & Bridge and Wesley (1968) \\
\hline & & Waste sludge & $4.1 \times 10^{3} \mathrm{ml}^{-1}$ & Bridge (1970) \\
\hline & & & $114.3 \times 10^{6}-752.3 \times 10^{6}$ colonies $/ \mathrm{ml}$ & Bridge and Wesley (1968) \\
\hline
\end{tabular}

receive more heat and are therefore adequately processed. In addition, it is necessary to know how heat resistant microorganisms are in order to define time and temperature for the process.

A general model for description of microbial reduction is given by (Paul and Dennis, 2001):

$N=N_{0} \times 10^{-t / D_{T}}$

This model is used to predict survivor population $(N)$ when the initial populations $\left(\mathrm{N}_{0}\right)$ are exposed to elevated temperature during heating time $(t)$.

Every microorganism has its own characteristic heat resistance $\left(D_{T}\right)$, defined as the time required to reduce the population by $90 \%$ at a constant temperature (T) (James, 2006).

On the other hand, the process does not take place at constant temperature but involves distinct periods. During drying, the temperature at any location in the sewage sludge.

Traditional thermal processing has used the sensitive temperature parameter $(z)$ to describe the influence of tem- perature on decimal reduction time for microbial population (James, 2006; Paul and Dennis, 2001; Durance and Wong, 1992). The thermal resistance constant ( $\mathrm{z}$ ) is defined as the temperature increase required to cause a one log cycle reduction in the decimal reduction time (Abdul and Mohammed, 2006). Based on the definition, the relationship between $(D)$ values at two different temperatures and the $(z)$ value can be expressed by the following equation:

$D_{1}=D_{2} \times 10^{\left(T_{2}-T_{1}\right) / z}$

\subsection{Heat resistance of microorganisms}

The practical and theoretical aspects of alternatives to the $(D-z)$ values concept have been discussed in reference Donald and Ricardo (2007), including the different methods of determining heat resistance. Some comparative $(D-z)$ values for bacteria, fungi and viruses are reported in Table 3.

Pathogens inactivation increase with increasing temperature and treatment duration. It was reported in reference 
Table 3 - Values of decimal reduction time (D) at test temperature (T) and temperature sensitive parameter (z) for pathogens inactivation.

\begin{tabular}{|c|c|c|c|c|}
\hline Pathogens & $\mathrm{T}\left({ }^{\circ} \mathrm{C}\right)$ & $D_{\mathrm{T}}(\mathrm{s})$ & $\mathrm{z}\left({ }^{\circ} \mathrm{C}\right)$ & References \\
\hline \multicolumn{5}{|l|}{ Bacteria } \\
\hline Salmonella & $55-70$ & $1444.26-5.82$ & $0.2964-0.9049$ & Murphy et al. (2002a) \\
\hline Listeria & $55-70$ & $3370.14-7.56$ & $0.318-0.9699$ & \\
\hline Escherichia coli & $55-70$ & $1281.6-1.86$ & 5.08 & Murphy et al. (2006) \\
\hline Mycobacterium & $62-68$ & $228.8-21.8$ & 7.11 & Nackmoon and Michael (1998) \\
\hline Campylobacter & $55.4-61.2$ & 89-10.3 & 6.1 & Moore and Madden (2001) \\
\hline \multicolumn{5}{|l|}{ Virus } \\
\hline \multirow[t]{2}{*}{ Hepatitis A } & 80 & $73.2-733.2$ & $11.26-21.41$ & Deboosere et al. (2004) \\
\hline & 90 & $13.2-180$ & & \\
\hline \multicolumn{5}{|l|}{ Fungi } \\
\hline Botrytis cinerea & $40-48$ & $1800-36$ & 4.65 & Marquenie et al. (2002) \\
\hline Monilinia fructigena & $39-45$ & $1302-150$ & 4.17 & Marquenie et al. (2002) \\
\hline \multirow[t]{2}{*}{ Monascus rubber ascospores } & 70 & 2238-4379 & 0.99 & Efstathios et al. (2002) \\
\hline & 80 & 52-126 & & \\
\hline
\end{tabular}

Marco et al. (2002) different thermal inactivation of Poliovirus in water and yoghurt. For example the heating at $55-62^{\circ} \mathrm{C}$ for $32 \mathrm{~min}$ results in complete inactivation of Poliovirus. At $71^{\circ} \mathrm{C}$ inactivation is limited at $30 \mathrm{~s}$ and only $15 \mathrm{~s}$ at $95^{\circ} \mathrm{C}$. A comparison of inactivation kinetic of different viruses by heat treatment at $60^{\circ} \mathrm{C}$ shows a higher heat resistance of Hepatitis A than other Enteroviruses (Nissen et al., 1996). In fact, Hepatitis A appears to be much more pertinent model to study the thermal inactivation of viruses. The $(z)$ values of Hepatitis $A$ are considerably elevated $\left(11.26-21.41^{\circ} \mathrm{C}\right)$ and $(D)$ values at incubated temperature of $80-90^{\circ} \mathrm{C}$ vary between 1.22 and 12.22 min (Deboosere et al., 2004).

In reference Marquenie et al. (2002), complete fungi spores inactivation is already achieved upon treatment at $48^{\circ} \mathrm{C}$ during $3 \mathrm{~min}$ and during $15 \mathrm{~min}$ at $43^{\circ} \mathrm{C}$. Other studies (Civello et al., 1997) show that most fungi spores on fruit and vegetable are inactivated when exposed to a temperature of $60^{\circ} \mathrm{C}$ for 5-10 min. The ( $\mathrm{z}$ ) value for most heat-resistant spores is about $10^{\circ} \mathrm{C}$ (Paul and Dennis, 2001), whereas lower values vary from 4.17 to $7.9^{\circ} \mathrm{C}$ (Marquenie et al., 2002; Efstathios et al., 2002). The decimal reduction time for the different temperatures ranging between 40 and $48^{\circ} \mathrm{C}$ varies from 0.607 to $29.959 \mathrm{~min}$ (Marquenie et al., 2002) and from 1.66 to $37.31 \mathrm{~min}$ at a temperature between 70 and $80^{\circ} \mathrm{C}$ (Efstathios et al., 2002).

To summarize the results obtained on heat inactivation of bacteria in sludge in reference Ward and Brandon (1977), it appears that moderate heat treatment $\left(55-60^{\circ} \mathrm{C}\right)$ during around $30 \mathrm{~min}$ is sufficient to eliminate pathogenic bacteria in both liquid system and in composted sludge. Thermal inactivation $(D)$ and $(z)$ values of Salmonella and Listeria in poultry product were reported in reference Murphy et al. $(2002 a, b)$. The $(z)$ values of both bacteria are the same magnitude $(0.3<(z)<0.9)$. Whereas, the $(z)$ values of Campylobacter, Escherichia coli and Mycobacterium are considerably higher (6.1 ${ }^{\circ} \mathrm{C}$ (Moore and Madden, 2001), $5.08^{\circ} \mathrm{C}$ (Murphy et al., 2006) and $7.11^{\circ} \mathrm{C}$ (Nackmoon and Michael, 1998), respectively).

While thermal resistance of pathogenic bacteria, fungi and viruses are thoroughly studied, heat inactivation of parasites is poorly investigated. In fact, considerations of pathogen inactivation must include effects of heat on parasite in bio-solids. Although heat inactivation of Ascaris Lumbricoides Ova in water was studied in reference Ward and Brandon (1977), showing that the moderate temperatures $\left(51-60^{\circ} \mathrm{C}\right)$ are effective in eliminating viability of these Ova in water and liquid sludge during 5-60 min processing.

\section{Thermal drying processing}

Sewage sludge drying systems were studied for pathogens destruction by numerical simulation. Four thermal treatment processes were compared: (1) a fry-drying process, (2) an agitated conductive drying process, (3) an indirect drying in thin film and (4) a solar drying system. Each drying system induces various mechanisms occurring within the sewage sludge. Commonly, heat drying is based on exposing sewage sludge to heating agent by direct or indirect contact long enough to attain at least $4 \%$ moisture content.

\subsection{Fry-drying}

Fry-drying is based on immersing the sewage sludge in a heated non-miscible fluid (animal fat, waste oil, etc.). Frying temperature can range from $110^{\circ} \mathrm{C}$ to $180^{\circ} \mathrm{C}$ under atmospheric conditions (Peregrina et al., 2006; Romdhana et al., 2008), and from $95^{\circ} \mathrm{C}$ to $115^{\circ} \mathrm{C}$ under vacuum (Mariscal and Bouchon, 2008). Frying conditions were selected in order to operate under low heating conditions but ensure sewage sludge disinfection at high temperature. Therefore, the frying temperature was followed in vacuum frying experiment $\left(95^{\circ} \mathrm{C}\right.$ of oil temperature and 0.6 bar of pressure). A cylindrical sludge samples (8 $\mathrm{mm}$ diameter) are immersed in jacketed cylindrical reaction vessel (Fig. 1a). The sewage sludge-to-oil weigh is chosen as low as possible ( $10 \mathrm{ml}$ per $400 \mathrm{ml}$ oil) in order to keep constant the frying temperature. The product temperature history is monitored using a thin thermocouple $(2 / 10 \mathrm{~mm}$ wire diameter and $5 / 10 \mathrm{~mm}$ welding thickness). Moisture loss during frying is modelled using the basic one dimensional mass diffusion equation. Oil temperature dependency of mass diffusivity model proposed by Romdhana et al. (2008) is considered. The trend of temperature results at the centre of product during vacuum frying is shown in Fig. 2. The temperature rises with progress in frying until it reaches the boiling point of water, $80^{\circ} \mathrm{C}$. Then, the temperature remains stable since heat supplied is being spent on moisture evaporation. After around 20 min of frying the product reaches less than $10 \%$ moisture content and the temperature start increasing again.

\subsection{Conductive drying by agitation}

The second process consists of conductive drying with agitation. The process is classified as indirect heating where the 
(a)

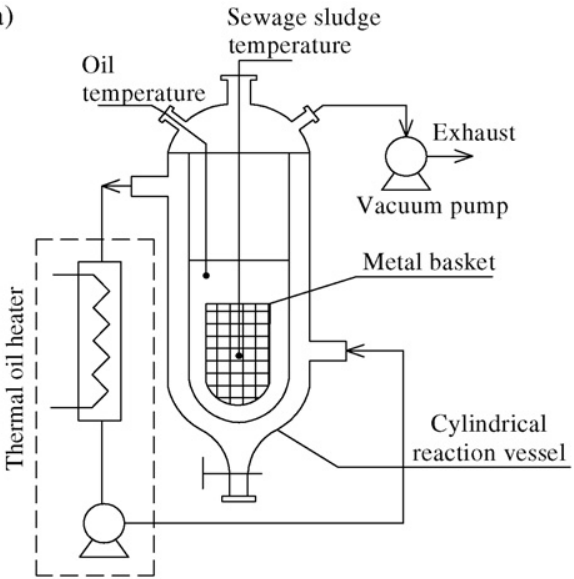

(b)

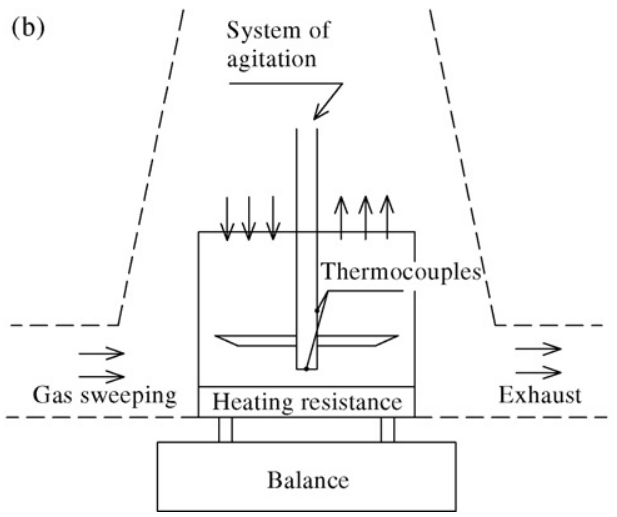

(c)

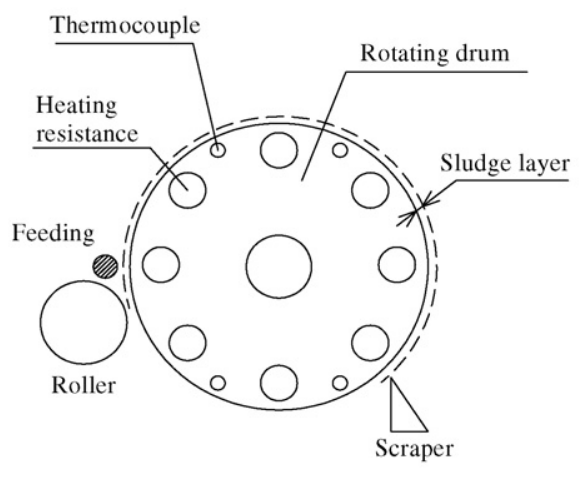

(d)

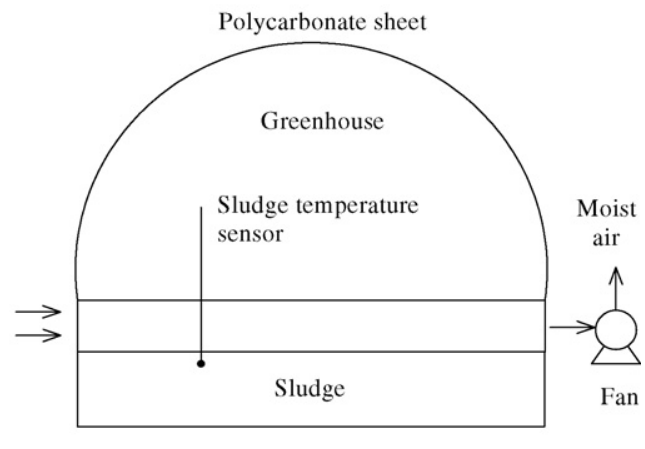

Fig. 1 - Detail of the experimental setup, (a) fry-drying, (b) agitated conductive drying, (c) indirect drying in thin film, and (d) solar drying.

heat transfer agent (resistance, fluid, etc.) and the product are separated by a wall. During the process the wet sewage sludge is kept in contact with a heated steel shell using a mechanical system of agitation (paddle, blades, scrappers, etc.). The moisture loss is determined from continuous weighing method as schematized in Fig. 1b. The temperature of the product is measured by thermocouples placed on the axis of the agitator at various positions. Typical data of an agitated laboratory scale conductive dryer are reported in reference Ferrasse (2000). Fig. 3 shows the temperature histories during the drying at $120^{\circ} \mathrm{C}$ temperature set up. The product temperature increases up to $100^{\circ} \mathrm{C}$ at the beginning, then decreases to lower values between 100 and $80^{\circ} \mathrm{C}$, inducing a slowing of the drying and a decrease of the heat exchange. When the moisture content decreases until 2 (dry basis), the temperature starts increasing

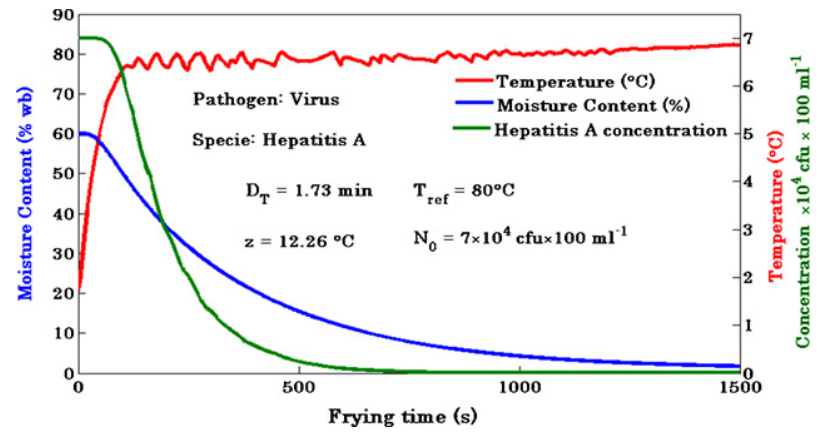

Fig. 2 - A survivor curve for a Hepatitis A virus population during fry-drying process.

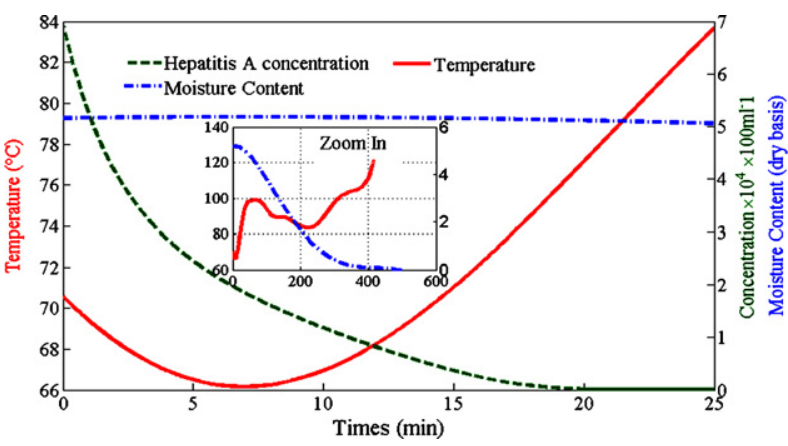

Fig. 3 - A survivor curve for a Hepatitis A virus population, temperature hitory and moisture loss during an agitated conductive drying process.

again. The quantities of $2.2 \mathrm{~kg}$ of sewage sludge are completely dried after about $7 \mathrm{~h}$.

\subsection{Drum drying}

In drum drying, the feed of sewage sludge is applied in a thin film $(1 \mathrm{~mm})$ to the surface of a rotating hollow cylinder, heated internally. The drying of aluminium hydroxide sludge on an electrically heated laboratory drum dryer is described in reference Carrère-Gée (1999). The kinetics of drying cannot be given directly while weighing. They are given indirectly by the energy balance by measuring the heat flow lost by the rotating drum and yielded to sewage sludge for the vaporization of the moisture contained in this one. Four thermocouples are positioned in the rotating drum as shown in Fig. 1c. The product 


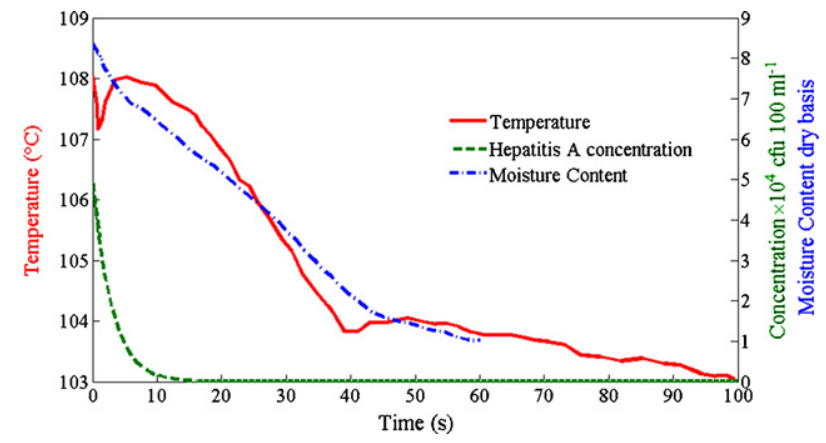

Fig. 4 - A survivor curve for a Hepatitis A virus population, temperature history and moisture loss during a drying of aluminium hydroxide sludge film by direct contact with a heated surface at $112^{\circ} \mathrm{C}$.

temperature is assumed to be those measured by the given thermocouples, because of the highest thermal density in the metal of the rotating drum. The drum surface temperature to which the sludge layer is exposed during evaporative phase is relatively high $\left(112-137^{\circ} \mathrm{C}\right)$. Therefore, drying times are considerably short (10-60 s). Fig. 4 shows the kinetic of drying and temperature of the crossing point between heating surface and sludge film for an experiment at $112^{\circ} \mathrm{C}$.

\subsection{Solar drying}

In solar drying, the sludge is lard down in a solar green house (Fig. 1d), thus the ambient temperature is raised above outside temperature. Under these conditions the sludge are dried by convection. Generally, this process requires air circulation to transport the moist air as fast as possible out of the drying zone, otherwise the vapour pressure difference between the sludge and the air decreases and the drying stops (Luboschik, 1999). The solar system may be completely covered with a transparent roof and wall, thus providing the greenhouse effect during the daylight and therefore accelerating the drying rate $\left(11^{\circ} \mathrm{C}\right.$ sludge temperature higher than open system) (Nezih et al., 2006). The kinetics of drying and the temperature variation of a typical covered solar system are shown in Fig. 5, also obtainable in reference Nezih et al. (2006). Drying time is long; it takes about 55 days for the sludge to reach a final moisture content of about $12 \%$.

\subsection{Microbial inactivation}

Microbial inactivation is described in term of the first order equation (1). The model is tested against experiment of deep

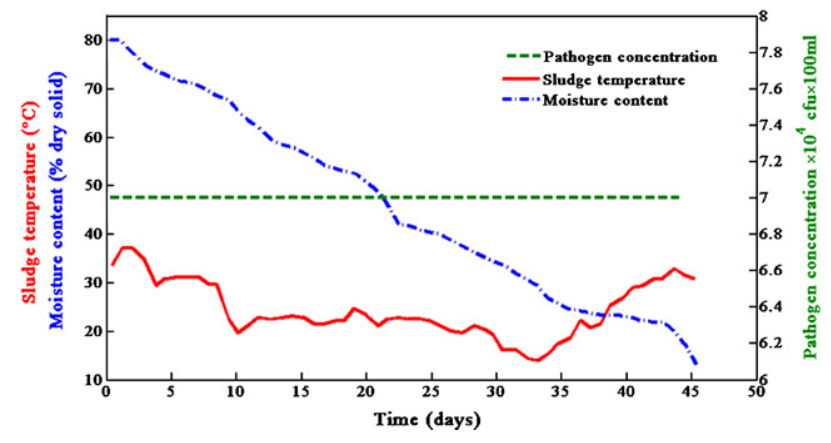

Fig. 5 - A survivor curve for pathogen population, temperature history and moisture loss during a drying of sewage sludge in covered solar system.

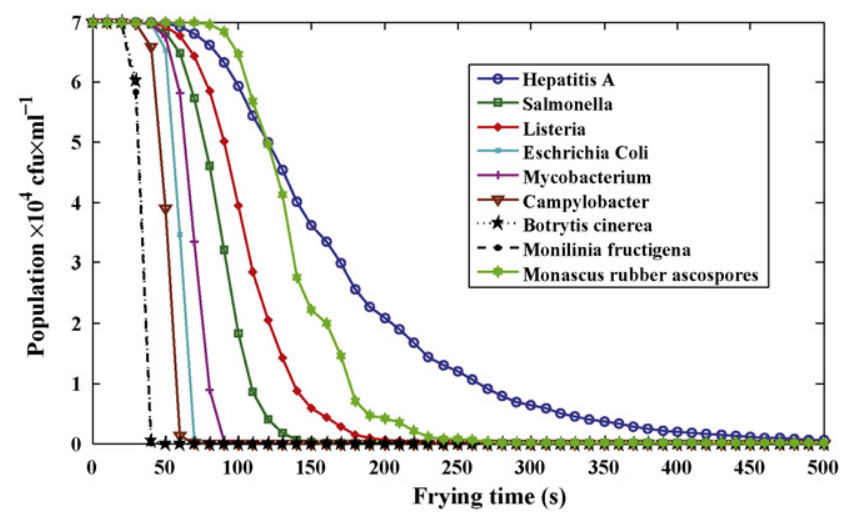

Fig. 6 - Comparison of pathogen survivor curve during frying time.

fat frying and available data in the literature for agitated convective system (Ferrasse, 2000), drying of thin film (CarrèreGée, 1999) and sun drying (Nezih et al., 2006). Hepatitis A virus appears to be a much more relevant model to study the dry inactivation process of sewage sludge pathogens. As shown in Fig. 6 which compares pathogens inactivation during vacuum frying, Hepatitis A virus is more resistant. At the beginning of the frying process, Hepatitis A concentration remains constant (Fig. 2). When the sludge temperatures reach $75^{\circ} \mathrm{C}$, the concentration starts to decrease sharply. After about $10 \mathrm{~min}$ of frying the sludge is disinfected. In spite of the high temperature in the agitated conductive process, the virus survives for $20 \mathrm{~min}$ (Fig. 3). In fact, this is explained by the low thermal penetration in the sewage sludge when it is introduced by large quantities. However, heat penetration is faster with thin sludge exposed to a hot surface $\left(112^{\circ} \mathrm{C}\right)$. The concentration is sharply reduced in $10 \mathrm{~s}$ (Fig. 4). While drying time is very long (55 days) in a solar plant, sludge temperature remains very low (reach hardly $38^{\circ} \mathrm{C}$ ). The simulation results under this condition show that all pathogens can survive for long period (Fig. 5). Experimental result for Fecal Coliform bacteria shows a very high concentration of this microorganism after 43 days (Nezih et al., 2006). This process requires chemical treatment to reduce pathogenic number in sewage sludge such as lime addition.

\section{Conclusion}

The first part of this work identifies principal diseases related to urban and industrial sewage sludge. Viruses are classified as the most pathogenic microorganism. Diseases caused by viruses range from trivial to severe or even fatal almost with Hepatitis A virus. A wide variety and concentration range are reported from literature. The examination of pathogenic occurrence is reported from various source involving different factors such as: wastewater treatment stage, some environmental factors ( $\mathrm{pH}$, water activity, salt, temperature, etc.), and method of analyse used in experiments. Composting and digestion greatly reduces pathogens during wastewater treatment plant. Several microorganisms are most resistant to heat at their optimum $\mathrm{pH}$ which is generally about 7 . The heat resistance increases with decreasing humidity, moisture or water activity. Some chemical compound have a protective effect on microorganisms, and other tend to make pathogens more heat sensitive such as chlorine or lime.

The principle of thermal inactivation was described. $(D-z)$ are important parameters to characterize heat resistance of 
each microorganism. They are also used to quantify the thermal and the time process required for a given microbial population. Typical values reported from literature for major pathogens show different tendencies of cells inactivation.

The final part of this study was focused on the comparison of four thermal drying processes namely the vacuum fry-drying, an agitated conductive drying, the direct contact with a heated surface, and the solar drying plant. Both information of temperature history and drying rate of each process are necessary to analyse heat penetration and its effect on microorganism inactivation. Based on the simulation results of microbial inactivation model, process time for reduction of Hepatitis A virus is higher than other microorganism. The prediction of pathogen disinfection during different thermaldrying process shows that the heat drying at high temperature are more efficient. The Hepatitis A virus is completely reduced when heated for $20 \mathrm{~min}, 10 \mathrm{~min}$ and $10 \mathrm{~s}$, respectively, during the agitated conductive process, vacuum fry-drying, and direct contact with a heated surface. Moreover, during solar drying, pathogens still survive for long period.

\section{Acknowledgments}

The authors thank French Agency of Environment and Energy (ADEME), Midi-Pyrénées Region. Authors which to thank particularly Mr. Bernard Auduc and Mr. Jean-Claude Poussin who have contributed to the design and run of most experiments in the RAPSODEE Centre, Ecole Des Mines d'Albi-Carmaux.

\section{References}

Abdul, G.A.-B. and Mohammed, F., (2006). Chap. Principles of thermal sterilization. In Sterilization of Food in Retort Pouches. (Springer), pages 25, 32

Ahlstrom, S.B., 1988, Irradiation of municipal sludge for pathogen control: why or why not? Radial. Phys. Chem., 31(1,3): 131-138.

Ali-Shtayeh, M.S., Rana, M.F.J. and Abu-Ghdeib, S.I., 1998, Ecology of cycloheximide-resistant fungi in field soils receiving raw city wastewater or normal irrigation water. Mycopathologia, 144(1): 39-55.

Anna, S. and Johan, S., 2006, Fungal survival during anaerobic digestion for organic household waste. Waste Manage. (Oxford), 26: 1205-1211.

Anna, M. and Richard, J.M., (2006). Chap. Foodborne viruses: an emerging risk to health. In Food Safety. (Springer), pages 202, 221

Aurelio, L.M., Enrique, P., Maribel, J.F., Stella, M.A. and Sandra, G., 2004, Multifactorial fungal inactivation combining thermosonication and antimicrobials. J. Food Eng., 67: 87-93.

Björn, V., 2007, Comparison of composting, storage and urea treatment for sanitising of faecal matter and manure. Bioresour. Technol., 98: 3317-3321.

Bosch, A., Lucena, F. and Jofre, J., 1986, Fat of human enteric viruses (rotaviruses and enteroviruses) in sewage after primary sedimentation. Water Sci. Technol., 18: 1413-1418.

Bosch, A., Pintó, R.M. and Abad, F.X., (2006). Chap. Survival and transport of enteric viruses in the environment. In Viruses in Foods. (Springer), pages 151, 187

Bourgeois, C.M., Mescle, J.F. and Zucca, J., 1996, Microbiologie alimentaire, Aspect microbiologique de la sécurité et de la qualité des aliments, Collection Sciences \& Techniques Agroalimentaires, vol. 1.

Bridge, C.W.M., 1970, Fungi associated with the activated sludge process of sewage treatment at the Lebanon, Ohio, sewage treatment plant. The Ohio J. Sci., 70: 129-146.

Bridge, C.W.M. and Wesley, O.P., 1968, The occurrence of fungi in activated sludge, In 23rd Industrial Waste Conference May 7-9,
Carrère-Gée, C., 1999, Etude du séchage indirect d'une fine couche de boue d'hydroxyde d'aluminium en ébullition, application au cylindre sécheur, Ph.D. thesis, Centre Energétique et Environnement de l'Ecole Des Mines d'Albi-Carmaux, France.

Civello, P.M., Martinez, G.A., Chaves, A.R. and Anon, M.C., 1997, Heat treatments delay ripening and postharvest decay of strawberry fruit. J. Agric. Food Chem., 45: 4589-4594.

Clint, W., Wei-Yin, C., Nazih, K.S. and Lawrence, K.W., (2007). Chap. Lime stabilization. Biosolids Treatment Processes (Springer), pages 207, 241

Deboosere, N., Legeay, O., Claudrelier, Y. and Lange, M., 2004, Modelling effect of physical and chemical parameters on heat inactivation kinetics of hepatitis a virus in a fruit model system. Int. J. Food Microbiol., 93: 73-85.

Donald, H. and Ricardo, S., (2007). Chap. Kinetics of thermal processing. In Thermal Processing of Packaged Foods. (Springer), pages 87,122

Durance, T.D. and Wong, N.S., 1992, Kinetics of thermal inactivation of avidin. Food Res. Int., 25: 89-92.

Efstathios, Z.P., Constantinos, Z.K. and George-John, E.N., 2002, Heat resistance of monascus rubber ascospores isolated from thermally processed green olives of the conservolea variety. Int. J. Food Microbiol., 76: 11-18.

EPA, 1979, Process Design Manual for Sludge Treatment and Disposal, Tech. rept. U.S. Environmental Protection Agency.

EPA, 1995, Process Design Manual Land Application of Sewage Sludge and Domestic Septage, Tech. rept. U.S. Environmental Protection Agency.

Ferrasse, J.-H., 2000, Développement dóutils expérimentaux pour le dimensionnement de procédés de séchage conductif avec agitation: Application à des boues de stations d'épuration urbaines, Ph.D. thesis, Centre Energétique et Environnement de l'Ecole Des Mines d'Albi-Carmaux, France.

Gantzer, C., Gaspard, P., Galvez, L., Huyard, A., Dumouthier, N. and Schwartzbrod, J., 2001, Monitoring of bacterial and parasitological contamination during various treatment of sludge. Water Resour., 35: 3763-3770.

Guzmán, C., Jofre, J., Montemayor, M. and Lucena, F., 2007, Occurrence and levels of indicators and selected pathogens in different sludges and biosolids. J. Appl. Microbiol., 103(6): 2420-2429.

Hersom, A.C. and Hulland, E.D., (1980). Canned Foods. Thermal Processing and Microbiology (7 edn.). (Churchill Livingstone, Edinburgh).

Ian, L.P., John, P.B. and Charles, P.G., (2006). Chap. Pathogens in biosolids. Advances in Agronomy (Elsevier), pages 1, 41

Irshad, M.S. and Vitaliano, C., (2006). Chap. The biology of giardia parasites. In Foodborne Parasites. (Springer), pages 15, 32

James, G.B., (2006). Food Processing Handbook. (WILEY-VCH Verlag $\mathrm{GmbH} \& \mathrm{Co} . \mathrm{KGaA}$, Weinheim).

James, M.J., Martin, J.L. and David, A.G., (2008a). Chap. Culture, microscopic, and sampling methods. In Modern Food Microbiology. (Springer), pages 217, 240

James, M.J., Martin, J.L. and David, A.G., (2008b). Chap. Foodborne gastroenteritis caused by Vibrio, Yersinia, and Campylobacter Species. In Modern Food Microbiology. (Springer), pages 657, 678

Joret, J.C., Block, J.C., Lucena-Gutierrez, F., Schwartzbrod, L., Hugues, B. and Plissier, M., 1980, Virus concentration from secondary wastewater: comparative study between epoxy fiberglass and glass powder adsorbents. Appl. Microbiol. Biotechnol.

Joseph, P.G., (2003). Microbiologie Alimentaire. (Dunod, Paris).

Lawrence, K.W., Paul, C. and Robert, Z., (2007). Chap. Irradiation and solid substances disinfection. Biosolids Treatment Processes (Springer), pages 331, 351

Lawrence, K.W., Clint, W., Wei-Yin, C. and Nazih, K.S., (2007). Chap. Low temperature thermal treatment processes. Biosolids Treatment Processes (Springer), pages 299, 329

Leena, S., Anna, A., Elisabeth, B., Danielsson, T.M.L. and Ann, A., 2004, Bacterial pathogen incidences in sludge from Swedish sewage treatment plants. Water Res., 38: 1989-1994.

Luboschik, U., 1999, Solar sludge drying based on the IST process. Renew. Energy, 16: 785-788. 
Marco, S., Johannes, K. and Barbara, B., 2002, Thermal inactivation of poliovirus type 1 in water, milk and yoghurt. Int. J. Food Microbial., 74: 73-78.

Mariscal, M. and Bouchon, P., 2008, Comparison between atmospheric and vacuum frying of apple slices. Food Chem., 107: 1561-1569.

Marquenie, D., Lammertyn, J., Geeraerd, A.H., Soontjens, C., Van Impe, J.F., Nicolai, B.M. and Michiels, C.W., 2002, Inactivation of conidia of botrytis cinerea and monilinia fructigena using uv-c and heat treatment. Int. J. Food Microbiol., 74: 27-35.

Millner, P.D., Marsh, P.B., Snowden, R.B. and Parr, J.F., 1977, Occurrence of aspergillus fumigatus during composting of sewage sludge. Appl. Environ. Microbiol., 34.

Moore, J.E. and Madden, R.H., 2001, The effect of thermal stress on campylobacter coli. J. Appl. Microbiol., 89: 892-899.

Murphy, R.Y., Duncan, L.K., Berrang, M.E., Marcy, J.A. and Wolfe, R.E., 2002, Thermal inactivation d- and z-values of salmonella and listeria innocua in fully cooked an vacuum packaged chicken breast meat during postcook heat treatment. Poultry Sci., 81: 1578-1583.

Murphy, R.Y., Duncan, L.K., Johnson, E.R., Davis, M.D. and Smith, J.N., 2002, Thermal inactivation d- and z-values of salmonella serotypes and listeria innocua in chicken patties, chicken tenders, franks, beef patties, and blended beef and turkey patties. J. Food Protect., 65: 53-60.

Murphy, R.Y., Davidson, M.A. and Marcy, J.A., 2006, Process lethality prediction for Escherichia coli o157:h7 in raw franks during cooking and fully cooked franks during post-cook pasteurization. J. Food Sci., 69: 112-116.

Nackmoon, S. and Michael, T.C., 1998, Thermal tolerance of mycobacterium paratuberculosis. Appl. Environ. Microbiol., 64: 999-1005.

Nazih, K.S. and Lawrence, K.W., (2007). Chap. Biosolids composting. Biosolids Treatment Processes (Springer), pages 645, 687

Nezih, K.S., Vedat, P. and Guray, S., 2006, Solar drying in sludge management in turkey. Renew. Energy, 32: 1661-1675.

Nissen, E., Konig, P., Feinstone, S.M. and Pauli, G., 1996, Inactivation of hepatitis a and other enteroviruses during heat treatment (pasteurization). Biologicals, 24(4): 339-341.

Paul, R.S. and Dennis, R.H., (2001). Food Engineering (3 edn.). (Food Science and Technology, International Series).

Peregrina, C., Arlabosse, P., Lecomte, D. and Rudolph, V., 2006, Heat and mass transfer during fry-drying of sewage sludge. Drying Technol., 24(7,9): 797-818.

Roberto, R. and Eloy, B., 2008, The occurrence of intestinal parasites in swine slurry and their removal in activated sludge plants. Bioresour. Technol., 99(14): 6661-6665.
Rolf, E., Paul, H.K. and Ray, K.L., (1991). Wastewater Engineering Treatment and Reuse (3 edn.). (McGraw-Hill, New York).

Romdhana, M.H., Ladevie, B., Hamasaiid, A. and Lecomte, D., 2008, Energy valorisation of industrial biomass: using a batch frying process for sewage sludge, In 2nd International Conference of Engineering for Waste Valorisation

Sabine, G. and Eleanora, I.R., 2000, Acidophilic and acid-tolerant fungi and yeasts. Hydrobiologia, 433(1,3): 91-109.

Sagar, M.G., (2007). Chap. Human and animal viruses in food (including taxonomy of enteric viruses). In Viruses in Foods. (Springer), pages 5, 42

Tchobanoglous, G., Burton, F.L. and Stensel, H.D., (2003). Wastewater Engineering Treatment and Reuse (4 edn.). (McGraw-Hill, New York).

Thaddeus, K.G., Malgorzata, K., Ewa, N., Leena, T., Halshka, G., Frances, E.L. and Autumn, S.G., 2008, Occurrence of cryptosporidium and giardia in sewage sludge and solid waste landfill leachate and quantitative comparative analysis of sanitation treatments on pathogen inactivation. Environ. Res., 106: 27-33.

Vantarakis, A. and Papapetropoulou, M., 1998, Detection of enteroviruses, adenoviruses and hepatitis a viruses in raw sewage and treated effluents by nested-pcr. Water Air Soil Pollut., 114: 85-93.

Ward, R.L. and Brandon, J.R., 1977, Effect of heat on pathogenic organisms found in wastewater sludge, In Composting of Municipal Residues and Sludge: National Conference August,. Pages 122, 134

Werther, J. and Ogada, T., 1999, Sewage sludge combustion. Prog. Energy Combust. Sci., 25: 55-116.

Wéry, N., Lhoutellier, C., Ducray, F., Delgenèse, J.F. and Godon, J.J., 2008, Behavior of pathogenic and indicator bacteria during urban wastewater treatment and sludge composting, as revealed by quantitative pcr. Water Res., 42 : 53-62.

Williams, F.P. and Hurst, C.J., 1988, Detection of environmental viruses in sludge: enhancement of enterovirus plaque assay filters with 5-iodo-2' deoxyuridine and comparison to adenovirus and coliphages titers. Water Resour., 7: 847851.

Ynes, R.O., (2006). Chap. Food-borne nematode infections. In Foodborne Parasites. (Springer), pages 135, 160

Zenker, M., Heinz, V. and Knorr, D., 2003, Application of ultrasound-assisted thermal processing for preservation and quality retention of liquid foods. J. Food Protect., 26: 1642-1649. 